\title{
WEEDS MANAGEMENT IN ORGANIC FARMING THROUGH CONSERVATION AGRICULTURE PRACTICES
}

\author{
Khagendra Raj Baral ${ }^{1}$
}

\begin{abstract}
Despite weeds are a serious threat to promotion of organic farming, relatively less attention is given to research on weed management. This article explores a scope of integration of conservation agriculture for weed control and soil protection under organic farming. Limitation in the use of agro-chemicals under OF promotes intensive tillage for weed control. Mostly, tillage leads to depletion of organic matter and proneness to erosion in inclined geography. Adoption of conservation agriculture reduces the intensity of soil manipulation thereby creates an unfavourable condition for weed seed germination, reduces the organic matter depletions and soil erosions. Residues on the surface invite weed and pest predators thereby reduced the weed and pest infestations in organic field. Appropriate crop rotations and cover crops management suppress weeds populations with smothering and allopathic effects. Thus, CA integration under OF could be an option for weed, pest and soil management which leads to sustainable organic plant production.
\end{abstract}

Key words: conservation agriculture, erosion, organic matter, tillage, weeds

\section{INTRODUCTION}

Weeds are often a major threat in organic farming (OF) and it seems as a key bottleneck for a promotion of sustainable organic plant production (Clark et al., 1998; Bàrberi, 2002). Globally, near about34\% of potential crop yield is reduced by weeds(Oerke, 2006) and yield reduction is more severe under OF systems because of banned in agrochemicals use(Nikolich et al., 2011). In Nepal, herbicide consumption rates are increased by $\sim 400 \%$ in 2003 as compared to 1999under conventional farming for a weed control (Diwakar et al., 2008). Unavailability of appropriate weed control measures rather than the herbicides are the reasons behind it. Despite preventive, physical, biological and cultural measures are available for weed control under OF (Bàrberi, 2002), an intensive ploughing (physical measures) and other intercultural operations being often practicing(Peigné et al., 2007). Mostly, intensive manipulation of soil for weed control increases soil erosions and losses of soil carbon from the soil, especially in the hills and mountains parts of Nepal.

Chemical pesticides (Koirala et al., 2009) and fertilizers (Shrestha, 2010) were introduced in the early fifties in Nepal. Before introduction of agro-chemicals, almost all agricultural areas were organic by default. Interestingly, commercial organic farming was only started since early 1990s after realizing the hazards of agro-chemicals in human and environment (Pokhrel and Pant, 2009). A study conducted by Aryal et al., (2009) shows that demand and willingness to pay for organic product is increasing (13\% of consumers are willing to pay $50 \%$ premium and $58 \%$ consumers willing to pay up to $20 \%$ premium for organic product), whereas the production and productivity of organic products are low in Nepal. The primary reasons could be unavailability of organic inputs, lower crop yields, higher weed problems (Mader and Berner, 2012), lack of structured markets, improper counseling and lack of training on OF (Pokhrel and Pant, 2009). As a result, only 1000 hectares of total

1 Forum for Rural Welfare and Agricultural Reform for Development (FORWARD), Bharatpur-2, Kshetrapur P.O. Box 11, Chitwan, Nepal, ph.: +977 56527 623, Fax: +977 56521 523, email: baralkhagendra@yahoo.com 
cultivatable areas of country is occupied by OF which is not significant figure (Pokhrel and Pant, 2009). However, research on weed management and quantification of amount of yield losses by the weeds under organic farming is rarely done in Nepal.

Organic farming and conservation agriculture (CA) have two contradictory philosophies for a weed control. OF focuses in no-use of agro-chemicals and promotes intensive tillage for weed control (Bàrberi, 2002). CA is focused on three principles; i) less disturbance of soil by minimum tillage or zero-tillage and use of herbicides for suppression of weeds, ii)retention of sufficient residues on the soil surface, and iii) cover crops and crop rotations to control the weeds, pests and diseases, and protect the soil from erosions (Govaerts et al., 2009, Mader and Berner, 2012). In Nepal, intensive tillage practices in OF to get rid of weeds may be inappropriate technique to control the weeds because two-third of the country's territory comes under the hills and the mountains(UNDP, 2009). Intensive cultivation on the slopes may increase pace of soil degradation by loosening the soil (Acharya and Kafle, 2009). Similarly, concentration of $\sim 80 \%$ of total precipitation in the monsoon also triggers the losses of organic matter rich soil through erosion (UNDP, 2009).Soil organic matter depletion could be another hurdle to conversion from conventional farming to OF andsustainable OF promotion(Bond and Grundy, 2001).

In this context, this paper explores the possibility of integration of the principles of CA under OF to minimize the weed problems. Furthermore, it also explores the possibility of soil quality improvement, pest and diseases control through adoption of CA principles on organic farming.

\section{REDUCED TILLAGE AND WEED CONTROL}

Adoption of reduced tillage or zero tillage under OF slow-down the mineralization of organic matter, resulting slow release of nutrients from soil (Benech-Arnold et al., 2000). The International Federation of Organic Agriculture Movements standards (IFOAM, 2002) recommend that organic farmers should minimize loss of topsoil through minimal tillage, contour ploughing, crop selection, maintenance of soil plant cover and other management practices that conserve soil and should take measures to prevent erosion, compaction, salinization, and other forms of soil degradation'. Especially it is important for Nepal, where most of the areas are sensitive for erosions. Furthermore, adoption of minimum or zero-tillage decreases energy consumption and carbon oxide emissions (Holland, 2004). Williams et al. (2006) stated that intensive tillage under OF increases the environmental burden like global warming and eutrophication rather than its environmental benefit. Therefore, adoption of CA under OF improves the environmental, societal and economic performance in addition to lower weed population.

Reduced or zero-tillage tillage decreases the weed population through creating unsuitable conditions for weed seed germination (Benech-Arnold et al., 2000). Deep and frequent tillage foster for a higher weed population through exposing old and dormant weed seeds to suitable climate (Finch-Savage and Leubner-Metzger, 2006). Intensive tillage tends to increase the some annual weeds, such as, Chenopodium sp. and Papaverrhoeas by bringing the persistence seeds to the surface (Locke et al., 2002). Tillage also allows diffusion of oxygen from atmosphere into the soil, removes carbon dioxide from the soil, increases the amplitude of temperature and increase the nitrate level(Karssen and Hilhorst, 1992). All those factors help to break the dormancy of weed seed. Although, tillage helps to prepare good seedbed both for crop seeds and weed seeds, the germination rate and nutrient use efficiency of weeds seeds and seedlings would be higher in early stages and thus support for a higher weed population(Mohler, 1993). In addition, tillage also exposes the weed seeds to light and darkness whereby support to break the dormancy of majority of weed seeds (Wesson and Wareing, 1969). A brief sunlight exposure $(<10$ seconds) is sufficient for weed seed germination (Sauer and Struik, 1964). Thus, by reducing the intensity of tillage to minimum, weed populations can be suppressed under OF. 


\section{RESIDUES RETENTION AND WEED CONTROL}

As a principle of CA, at least $30 \%$ of the soil surface should retain with a residue (Peigné et al., 2007). However, burning of crop residues during land preparation is common in South Asia including Terai region of Nepal to prepare a good seed bed, and possible control of soil borne diseases and pests(Aulakh et al., 2001a). However, burning is not recommended in organic agriculture as it losses the soil carbon and increases the environmental pollutions(Woomer and Palm, 1998, Dinesh et al., 2009). By retaining the residues on the surface reduces the soil runoff by $52.5 \%$ and erosion by $80.2 \%$ compared to intensive tillage(Yan et al., 2000). Similarly, retention of residues help to increase the soil carbon content and suppress the weeds by modifying the microclimatic condition of soil (Robinson, 1998). In addition, presence of crop residues on the soil surface reduces the possibility of weed seed contact with the soil(Peigné et al., 2007), thus hinders the weed seeds germination rate(Bond and Grundy, 2001). Hence, residues retention on the surface could be a good soil management option for Nepal.

Development of predator habitats are important for promoting weed seeds predation and pest control under OF(Gallagher et al., 1999). Crop residues provide habitat and invite the diversity of beneficial insects, birds and a wide range of invertebrates (e.g. earthworms, small rodents, birds, carabid beetles, field crickets etc.) (Andersen, 2003). Availability of suitable habitats nearby the crop fields support for early colonization of natural enemies(Hunter, 2002). The field managed under minimum tillage or zero-tillage holds the weed seeds on the soil surface that increases the predation possibility of weed seed. For instance, Aphid (Sonchus spp.) is a good example of weed predator (Gallagher et al., 1999). Furthermore, closer habitats also support various beneficial insects such as parasitic wasps, lady beetles and syrphid flies, and those predators maintain the crop pest populations below the economic threshold (Norris and Kogan, 2000).

Use of farm yard manure and other crop residues in organic farming systems add organic matter into the soil, whereas improperly decomposed organic matter may become source of weeds(Pleasant and Schlather, 1994). For instance, one kilogram of cow manure contain 42 viable seeds of Chenopodium album(Pleasant and Schlather, 1994) and $20 \%$ of seeds can survive after passing from rumen of the animals and after storage(Bàrberi, 2002).An addition of organic matter increases the microbial activity in soil that potentially increases the weed seed decay (Gallagher et al., 1999). According to Lonsdale et al.(1988), an average $10-16 \%$ of seed of Mimosa pigra is lost with microbes and the rate of weed seeds decay speeds up in relatively warmer climate and a higher temperature. Similarly, McCloskey et al. (1996) observed a decline in a Stellaria media population over 3 years of poultry manure application. The residues on soil surface also help to maintain a higher soil moisture by lower evaporations and maintain favourable condition for microbial populations and accelerate the microbial decay of weed seeds through protecting them from excessive cold and hot temperature (Crist and Friese, 1993).

\section{COVER CROPS, CROP ROTATIONS AND WEED CONTROL}

Appropriate crop rotations and growing of cover crops during fallow period helps to suppress the weed population by smothering and allopathic effect(Peigné et al., 2007). Physical effects of cover crops are the most important to reduce weed population (Barberi, 2002). According to Teasdale et al. (2004), growing of wheat, maize and soybeans in rotation tends to decrease the weed seed bank and abundance of the broadleaf weed. A permanent residue covers or cover crops reduces the sunlight exposure of weed seeds and compete with the weeds for space and nutrient(Rajcan and Swanton, 2001). Use of the cover crops and organic amendments promotes the fungal, bacterial and mycorrhizal communities that may be detrimental to weeds and beneficial for the crops (Norris and Kogan, 2000). Similarly, IFOAM (2002) recommends intercropping to avoid the bare soils, reduce weed population and the erosion. 
The rotation of different crops with different rooting patterns promotes a more extensive network of root channels and macro-pores in the zero tilled soil(Hobbs, 2006). This helps in water infiltration to deeper depth and also increases microbial diversity, reduce the risk of pests and disease outbreaks from pathogenic organisms (Hobbs, 2006). Use of legumes as cover crops in rotation helps to fix the atmospheric nitrogen and add the soil carbon which may be utilized by the subsequent crop and improve the soil quality by making phosphorus and nitrogen available to plants(Lu et al., 2000). Leaving the field barren after harvesting of crop, substantial amounts of nitrate is leached out or flushed away from the field as an effect of higher nitrate-nitrogen available after harvest (Dinesh et al., 2009). Growing of non-legume crops in the rotation as a cover crop utilize the surplus nitrogen from the soil that prevent nitrate-nitrogen removal and also reduce the available nutrients for weed germination andits growth(Dinesh et al., 2009; Kuo et al., 1997; Sainju et al., 2007).

\section{OTHER BENEFITS OF CONSERVATION AGRICULTURE}

Continuous cultivation in hilly terraces without addition of substantial amount of soil organic matter causes the sharp decrease in soil organic carbon and nitrogen(Shrestha et al., 2006). Depletion of soil organic matter ultimately decreases soil fertility and productivity(Mathema et al., 1999). Increase in tillage rates change the soil structures and break the soil aggregates which trap the stable organic matter for a long period(Six et al., 2004). This accelerates the mineralization of the stable organic matter and emits CO2 as a product of organic matter decomposition (Six et al., 2004). Conservation tillage in organic farming systems improves the soil fertility by sequestering the soil organic carbon(Al-Kaisi and Yin, 2005). According to Six et al. (2002)maximum amount of soil organic matter is deposited on the top layer of soil in conservation tillage practices resulting high infiltration rate, reduced run off, increased microbial communities and increased binding capacity of soil particles (Six et al., 2004; Kladivko, 2001).

Conservation agriculture creates a favourable condition for microbial population (Alvear et al., 2005). A study conducted in Brazil shows that conservation tillage increases the soil organic matter by $45 \%$ and soil microbial population by $83 \%$ in 20 year's period in comparison with conventional tillage (Balota et al., 2004). A higher number of Microbial diversities reduce the population of parasitic nematodes (Pratylenchusthornei)(Govaerts et al., 2007).Zero-tillage increases the number and diversity of beneficial soil microbes which can compete with the harmful soil organisms and increase the yield of crops(Ramakrishna and Sharma, 1998). Further, reduced or zero-tillage improve the soil structure, increase the nutrient recycling and decrease the pesticides use, greenhouse gas emissions(e.g. Nitrous oxide), eutrophication and cost of the production (Holland, 2004).

\section{CONCLUSIONS}

The review study shows the integration of CA techniques and principles under OF seems reasonable for sustainable organic plant production in Nepal. Organic farms/farmers are mainly facing weed and organic matter depletion problems. Depletion of soil organic matter from the field and increased weed pressure limits to further OF promotion. Although a number of approaches have been used for weed control, adoption of CA principles could be an option for weed management under OF. Adoption of reduced or zero tillage makes an inappropriate environment for weed seed germinations. It also stores a higher amount of organic matter by reducing the mineralization rates and subsequently decreases energy consumption and carbon oxide emissions. Crop residues on the soil surface lower the possibility of weed seed germinations by creating obstruction for proper contact to the soil. Similarly, it invites the diversity of beneficial insects, birds and wide range of invertebrates by providing the habitats for weed seeds and pest predators. Maintaining appropriate crop rotation with legume and non-legume crops, and growing of cover crops during fallow period helps to suppress the weed population by smothering and 
allopathic effect. Even though, it is important to understand the dynamics of nature and applicability of available practices in different parts of Nepal by implementing field based practices for better understanding the prospect of integration of CA under OF.

\section{REFERENCES}

Acharya, A. K. and Kafle, N. 2009. Land degradation issues in Nepal and its management through agroforestry. Journal of Agriculture and Environment, 10, 133-143.

Al-Kaisi, M. M. and Yin, X. H. 2005. Tillage and crop residue effects on soil carbon and carbon dioxide emission in Corn-Soybean rotations. J. Environ. Qual., 34, 437-445.

Alvear, M., Rosas, A., Rouanet, J. L. and Borie, F. 2005. Effects of three soil tillage systems on some biological activities in an Ultisol from southern Chile. Soil and Tillage Research, 82, 195-202.

Andersen, A. 2003. Long-term experiments with reduced tillage in spring cereals. II. Effects on pests and beneficial insects. Crop Protection, 22, 147-152.

Aryal, K. P., Chaudhary, P., Pandit, S. and Sharma, G. 2009. Consumers' willingness to pay for organic products: a case from kathmandu valley. The Journal of Agriculture and Environment, 10, 12-22.

Aulakh, M., S., , Khera, T. S., Doran, J. W. and Bronson, K. F. 2001a. Managing crop residue with green manure, urea, and tillage in rice-wheat rotation. Soil Sci Soc Am J 65, 820-827.

Balota, E. L., Colozzi Filho, A., Andrade, D. S. and Dick, R. P. 2004. Long-term tillage and crop rotation effects on microbial biomass and $\mathrm{C}$ and $\mathrm{N}$ mineralization in a Brazilian Oxisol. Soil and Tillage Research, 77, 137-145.

Bàrberi, P. 2002. Weed management in organic agriculture: are we addressing the right issues? Weed Research, 42, 177-193.

Benech-Arnold, R. L., Sánchez, R. A., Forcella, F., Kruk, B. C. and Ghersa, C. M. 2000. Environmental control of dormancy in weed seed banks in soil. Field Crops Research, 67, 105-122.

Bond, W. and Grundy, A. C. 2001. Non-chemical weed management in organic farming systems. Weed Research, 41, 383-405.

Clark, M. S., Ferris, H., Klonsky, K., Lanini, W. T., Van Bruggen, A. H. C. and Zalom, F. G. 1998. Agronomic, economic, and environmental comparison of pest management in conventional and alternative tomato and corn systems in northern California. Agriculture, Ecosystems \& Environment, 68, 51-71.

Crist, T. O. and Friese, C. F. 1993. The Impact of fungi on soil seeds: implications for plants and granivores in a semiarid shrub-steppe. Ecology, 74, 2231-2239.

Dinesh, R., Chaudhari, S. G., Sheeja, T. E., Suryanarayana, M. A., Ganeshamurthy, A. N. and Shiva, K. N. 2009. cover crop effects on biochemical and biological parmeters reflecting soil quality. In: T.H. Latos (Ed.), Cover crops and crop yeilds, pp. 57-89.

Diwakar, J., Prasai, T., Panta, S. R. and Jayana, B. L. 2008. Study on major pesticides and fertilizers used in Nepal. Scientific World, 6,76-80.

Finch-Savage, W. E. and Leubner-Metzger, G. 2006. Seed dormancy and the control of germination. New Phytologist, 171, 501-523.

Gallagher, R., Fernandes, E. and Mccallie, E. 1999. Weed management through short-term improved fallows in tropical agroecosystems. Agroforestry Systems, 47, 197-221.

Govaerts, B., Mezzalama, M., Unno, Y., Sayre, K. D., Luna-Guido, M., Vanherck, K., Dendooven, L. and Deckers, J. 2007. Influence of tillage, residue management, and crop rotation on soil microbial biomass and catabolic diversity. Applied Soil Ecology, 37, 18-30.

Govaerts, B., Verhulst, N., Castellanos-Navarrete, A., Sayre, K. D., Dixon, J. and Dendooven, L. 2009. Conservation Agriculture and Soil Carbon Sequestration: Between Myth and Farmer Reality. Critical Reviews in Plant Sciences, 28, 97-122.

Hobbs, P. R. 2006. Conservation agriculture : what is it and why is it important for future sustainable food production? Paper presented at International Workshop on increasing Whereat Yield Potential, СІМмYT, Mexico. 
Holland, J. M. 2004. The environmental consequences of adopting conservation tillage in Europe: reviewing the evidence. Agriculture, Ecosystems \& Environment, 103, 1-25.

Hunter, M. D. 2002. Landscape structure, habitat fragmentation, and the ecology of insects. Agricultural and Forest Entomology, 4, 159-166.

IFOAM, 2002. IFOAM basic standards for organic production and processing. IFOAM, Germany.

Karssen, C. M. and Hilhorst, H. W. M. 1992. Effect of chemical environment on seed germination. In: Fenner, M. (Ed.), Seeds. The Ecology of Regeneration in Plant Communities. CAB international, 327-348.

Kladivko, E. J. 2001. Tillage systems and soil ecology. Soil and Tillage Research, 61, 61-76.

Koirala, P., Dhakal, S. and Tamrakar, A. S. 2009. Pesticide applicaiton and food satety issue in Nepal. The Journal of Agriculture and Environment, 10, 111-114.

Kuo, S., Sainju, U. M. and Jellum, E. J. 1997. Winter cover crop effects on soil organic carbon and carbohydarate. Soil Sci. Soc. Am. J., 61, 145-152.

Locke, M. A., Reddy, K. N. and Zablotowicz, R. M. 2002. Weed management in conservation crop production systems. Weed Biology and Management, 2, 123-132.

Lonsdale, W. M., Harley, K. L. S. and Gillett, J. D. 1988. Seed Bank Dynamics in Mimosa pigra, an Invasive Tropical Shrub. Journal of Applied Ecology, 25, 963-976.

Lu, Y.-C., Watkins, K. B., Teasdale, J. R. and Abdul-Baki, A. A. 2000. Cover crops in sustainable food producition. Food Reviews International, 16, 121-157.

Mader, P. and Berner, A. 2012. Development of reduced tillage systems in organic farming in Europe. Renewable Agriculture and Food Systems, 27, 7-11.

Mathema, S. B., Shakya, P. B. and Pilbeam, C. J. 1999. Socio-economic research on management of soil fertility in Mid-Hills of Nepal. Soil science department, The University of Reading, UK.

McCloskey, M., Firbank, L. G., Watkinson, A. R. and Webb, D. J. 1996. The dynamics of experimental arable weed communities under different management practices. Journal of Vegetation Science, 7, 799-808.

Mohler, C. L. 1993. A model of the effects of tillage on emergence of weed seedlings. Ecological Applications, 3, 53-73.

Nikolich, L., Dzigurski, D., Ljevnaich-Masich, B., Cabilovski, R. and Manojlovich, M. 2011. Weedsoflattuce (Lactuca sativa L.) in organic agriculture. Bulgarian Journal of Agricultural Science, 17, 736-743.

Norris, R. F. and Kogan, M. 2000. Interactions between weeds, arthropod pests, and their natural enemies in managed ecosystems. Weed Science, 48, 94-158.

Oerke, E. C. 2006. Crop losses to pests. Cenenary review. Journal of Agricultural Science, 144, 31-43.

Peigné, J., Ball, B. C., Roger-Estrade, J. and David, C. 2007. Is conservation tillage suitable for organic farming? A review. Soil Use and Management, 23, 129-144.

Pleasant, J. M. and Schlather, K. J. 1994. Incidence of Weed Seed in Cow (Bos sp.) Manure and Its Importance as a Weed Source for Cropland. Weed Technology, 8, 304-310.

Pokhrel, D. M. and Pant, K. P. 2009. Perspectives of organic agriculture and policy concerns in Nepal. The Journal of Agriculture and Environment, 10, 103-115.

Rajcan, I. and Swanton, C. J. 2001. Understanding maize-weed competition: resource competition, light quality and the whole plant. Field Crops Research, 71, 139-150.

Ramakrishna, A. and Sharma, S. B. 1998. Cultural practices in rice-wheat-legume cropping systems: effect on nematode community. In: Sharma, S.B., Johansen,C., Midha, S.K. (Eds.), Nematode pests in rice-wheat-legume cropping systems: proceedings of a Regional Training Course, 1-5 September 1997, CCS Haryana Agricultural University, Hisar, India, pp. 73-79.

Robinson, D. W. 1998. Mulches and herbicides in ornamental plantings. Hortic.Sci, 23, 547-552. 
Sainju, U. M., Schomberg, H. H., Singh B. P., Whitehead, W. F., Tillman, P. G. and Lachnicht-Weyers, S. L. 2007. Cover crop effect on soil carbon fractions under conservation tillage cotton. Soil Tillage Res., 21, 205-218.

Sauer, J. and Struik, G. 1964. A possible ecological relation between soil disturbance, light-flash, and seed germination. Ecology, 45, 643-654.

Shrestha, R. K. 2010. Fertilizer policy development in Nepal. The Journal of Agriculture and Environment, 11, 126-137.

Shrestha, R. K., Ladha, J. K. and Gami, S. K. 2006. Total and organic soil carbon in cropping systems of Nepal. Nutr. Cycl. Agroecosyst, 75, 257-269.

Six, J., Feller, C., Denef, K., Ogle, S. M., De Moraes Sa, J. C. and Albrecht, A. 2002. Soil organic matter, biota and aggregation in temperate and tropical soils - Effects of no-tillage. Agronomie, $22,755-775$.

Six, J., Ogle, S. M., Jay Breidt, F., Conant, R. T., Mosier, A. R. and Paustian, K. 2004. The potential to mitigate global warming with no-tillage management is only realized when practised in the long term. Global Change Biology, 10, 155-160.

Teasdale, J. R., Mangum, R. W., Radhakrishnan, J. and Cavigelli, M. A. 2004. Weed seedbank dynamics in three organic farming crop rotations. Agron. J., 96, 1429-1435.

UNDP, 2009. Global assessment of risk; Nepal country report. ISDR global asessment report on poverty and disaster risk. Kathmandu, Nepal: United Nation Development Project ( UNDP).

Wesson, G. and Wareing, P. F. 1969. The induction of light sensitivity in weed seeds by burial. Journal of Experimental Botany, 20, 414-425.

Williams, A. G., Audsley, E. and Sandars, D. L. 2006. Energy and environmental burdens of organic and non-organic agriculture and horticulture. Aspects of Applied Biology, 79, 19-23.

Woomer, P. L. and Palm, C. A. 1998. An approch to estimationg system carbon stocks in tropical forests and associated land uses. Commonwealth Forestry Review, 77, 181-190.

Yan, W. X., Wen, G. H., Wen, L. H. and Xiang, Z. X. 2000. Experimental study on runoff and erosion under conservaton tillage. Transactions of the Chinese Society of Agricultural Engineering, 16, 6669. 